\title{
Towards a Technology-Enhanced Blended Approach for Teaching Arabic for Shari'ah Purposes (ASP) in the Light of the South African National Qualifications Framework
}

\author{
T. A. S. Mohammed, B. Al-Sowaidi, and F. Banda
}

\begin{abstract}
The study investigates the use of a blended learning approach for teaching Arabic as a foreign language at a South African Islamic college in the light of the South African National Qualifications Framework level descriptors and their critical cross-field outcomes. In particular, the approach has been used for teaching a Hadīth Module in an undergraduate BA programme during the second semester of the academic year 2018-2019 at the International Peace College South Africa (IPSA). The college adopts a content and language integrated approach for teaching Arabic. The study concluded that the use of a technology-enhanced blended approach using Web 2.0 tools and Learning Tools (with full) Interoperability (LTI 2.0) (e.g. gamification) plays a vital role in motivating the learners and in the achievement of critical cross-field outcomes of each NQF level including, subject knowledge, critical thinking and problem solving, communication, teamwork and self-management among others. The study is part of an action research project that also includes the design of a syllabus for teaching Arabic for Shari'ah purposes in the South African context and the attitudes of learners towards it.
\end{abstract}

Index Terms-Blended learning, Hadīth, ASSURE, instructional design, national qualifications framework (NQF).

\section{INTRODUCTION}

Thousands of academic programmes are currently offered throughout the world and new progarmmes are introduced annually. This diversity of programmes necessitated the need for regulatory principles to ensure that the output of such programs meets specific quality standards. Countries have therefore started to evaluate their programmes and they have come up with national qualification frameworks with a view to ensuring that all academic programmes develop the same level of learning outcomes expected irrespective of the institutions that offer the programme. This has become more pressing in this age of internationalization where students and graduates are moving from one country to another either to pursue a new degree or to join a workplace. Mere acquisition of knowledge has proven to be insufficient in our world today and learners are in bad need for a much wider range of learning outcomes and competencies. In response to this, South Africa represented by the South African Qualifications Authority (SAQA) released its first National

Manuscript received March 9, 2020; revised October 27, 2020.

T. A. S. Mohammed is with the International Peace College South Africa, South Africa (e-mail: tawffeek@gmail.com ).

B. Al-Sowaidi is with Taiz University, Yemen and the University of the Western Cape, South Africa (e-mail: balkis.20@gmail.com ).

F. Banda is with the University of the Western Cape, South Africa (e-mail: fbanda@uwc.ac.za ).
Qualification Framework (NQF) in 2012. The NQF stipulates 10 levels with a number of sub-competencies and critical cross-filed skills. In general, the number of levels does not imply the number of years and this explains the discrepancy in the number of levels in NQF in different countries.

The current study reports on an action research on teaching Arabic in a Hadith module at the International Peace College South Africa (IPSA). IPSA is a higher education Islamic institution that was accredited by the Department of Education in South Africa in 2013. It awards a BA in Islamic studies (equivalent to exit NQF level 7), a one-year Diploma in Islamic Studies (equivalent to level 5), an Honors degree (equivalent to NQF level 8) and recently a new Master's programme in Applied Islamic Thought (equivalent to NQF level 9) has been launched. Unlike other South African higher education institutions, which use either English or Afrikaans as a medium of instruction, the medium of instruction in IPSA is both Arabic and English. A considerable number of courses are mainly offered in Arabic. Arabic is taught for both general and specific purposes. In addition to the skills-based Arabic courses offered in all BA levels, Arabic is taught through the Qura'n, the Hadith (the prophetic tradition), Khutab (Islamic sermons), $d u ' a$ '(devotional Arabic) and sirrah (prophetic biography) modules. IPSA strives to offer a cost-effective programme in line with the NQF levels and their critical cross-field skills. It has therefore paid a lot of attention to recent pedagogical approaches and trends in the fields of foreign language pedagogy, Qura'nic and Hadìth Sciences as well as technology-enhanced instruction.

Teaching Arabic through Hadith is a key component of the Arabic programme at IPSA and it is offered in all levels of the BA programme. The Hadith modules are offered three periods per week (40 minutes each). In the first year, Sharh Al- 'Arba in Al-Nawawiyyah [Commentary on the Forty Hadiths of Imam $A l$-Nawawi] is offered, in the second year the Muwatta' [well-trodden path] of Imam Malik is taught and in the third year Kitāb al-Adab of the Riyā al-Ṣāliḥin by Imām al-Nawawī is offered.

\section{Statement OF THE PROBLEM}

As opposed to the proclaimed policy of teaching Hadith at Islamic schools and universities, the teaching methodology is traditional, and it hardly assists the learners to master the Arabic language skills. The class is sometimes rendered to a mere reading or translation of the Hadith and explanation of 
its new words. In addition, the selected $a$ hădīth are too short to teach the learners the various Arabic language skills. It is high time that Islamic institutions take the initiative to revisit Shari'ah modules including Hadith in terms of content and teaching methodology and in line with the skills and competencies stipulated in the National Qualifications Framework.

\section{NATIONAL QUALIFICATIONS FRAMEWORK (NQF)}

The National Qualifications Framework (NQF) can be defined as a framework for learning outcome-based qualifications, which includes a set of principles and guidelines for the classification of qualifications and the registration of learner achievement. It aims to integrate and coordinate national qualifications sub-systems in any country with an aim to ensure quality, transparency and to encourage progression and lifelong learning. The South African NQF includes 10 levels divided into three bands; Levels 1 to 4 are equal to high school grades 9 to 12 or vocational training, Levels 5 to 7 are college diplomas and technical qualifications, and levels 7 to 10 are university degrees, as is shown in the following figure.



Each of the above levels is identified by a unique set of Level Descriptors and each Level Descriptor is classified into ten competencies, namely, scope of knowledge, knowledge literacy, method and procedure, problem solving, ethics and professional practice, accessing, processing and managing information, producing and communicating of information, context and systems and management of learning and Accountability [1]. Those ten competencies can be compacted and categorized under three separate strands or domains namely, Knowledge, Skills and Competence.

It is clear that learning outcomes in the domain of knowledge which includes theoretical understanding as well as cognitive skills, are directly related to the field of study or profession for which students are being prepared. The second and third domains include skills such as communication, information technology and numeracy as well as competencies such as interpersonal skills and responsibility. These skills and competencies are general capabilities that all students are required to develop irrespective of their field of study, and the Shari'ah students are not an exception. However, substantially higher level of achievement might be required more in certain majors than others. The Hadith module under investigation is categorized under NQF level 5. At this level, learners are expected to demonstrate an informed understanding of various core areas such as Qura'nic sciences, Hadith terminology and science, prophetic biography, the foundations of Jurisprudence, etc. They should possess an informed understanding of the renowned 40 Ahādīth of Imām al-Nawawī in Arabic. These Ahädith cover the various essential aspects of the Islamic way of life, as meticulously compiled by Imām al-Nawawī. Learners need to get familiar with Muștalah al-Hadìth [the science of Hadith], its origin, history and key concepts (e.g. $R \bar{a} w \bar{l}, I s n \bar{a} d)$. They should have informed understanding of the different types of Hadith (e.g., Hādìth Mutawātir, Hadìth Sahìh, Hadìth Hasan, Hadìth Da'ìf and Hadìth Mawdī'), their authorities and authenticity. In terms of Applied knowledge, learners need to use basic skills to relate to the main theories and concepts. Students should utilize the theoretical knowledge they gained in day-to-day situations and scenarios. They can for instance apply the theoretical knowledge of inheritance while distributing the wealth of a deceased.

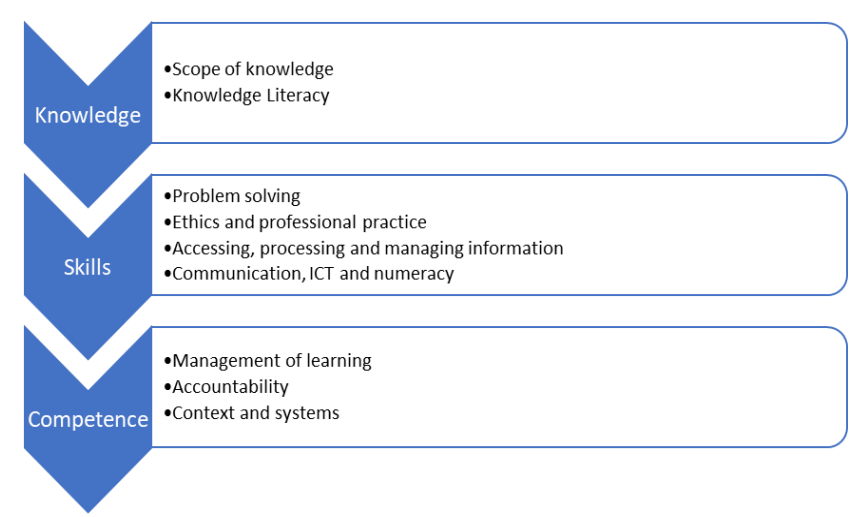

Fig. 2. Overview of NQF strands: Knowledge, skills and competence.

As for skills, learners with some guidance will be able to access, organise and use information. They may gather relevant ahädiths on a subject together or organize information from the Qura'n, Hadìth and poetry to deliver a Friday sermon. Learners are also expected to identify, evaluate and solve problems (e.g. should an adopted child inherit or not?). They need to draw conclusions and suggest solutions to such problems in the light of the Qur'an and Sunnah. At this level, learners are also expected to make generalisations and predictions in defined situations as is clear in fatwa issues. In addition, students need to demonstrate the ability to produce and respond to oral and written communication reliably, accurately and coherently, taking into account the conventions appropriate to the context. For instance, a Friday sermon is different from a 
funeral context. In so far as Autonomy, Responsibility and Context competencies are concerned, learners with some guidance should operate in familiar and unfamiliar scenarios and contexts; they can carry out defined tasks independently and take responsibility for the nature, results, quality and possible consequences of output.

Undoubtedly, a module alone will not serve as a magic wand to assist students to master all the skills and competencies of a particular NQF level. We are fully aware that those competencies are not the product of one module or one level. They are rather "cumulative i.e. there is progression in the competencies from one level to the next" [1]. The cross-filed skills will not be improved unsystematically but they need to be integrated into our teaching units/modules. The design of study units with very clear objectives and learner outcomes is badly needed. This can be achieved through the application of recent pedagogical approaches and instructional design models such as Bloom's taxonomy, ASSURE and ADDIE. Taking into consideration the limitations of time, the above skills can be effectively enhanced through the utilization of blended learning.

\section{BLENDED LEARNING}

The concept of blended learning has been approached and interpreted differently by different scholars. The debate among scholars has resulted in a plethora of terms including blended learning, mediated learning, hybrid instruction, web-assisted or web-enhanced instruction [2]. Blended learning can be simply defined as the mixture and infusion of traditional teaching methods with online learning for students who are studying the same content in the same course. It is a "thoughtful fusion of face-to-face and online learning experiences" [3]. Some scholars called the online learning 'distributed learning' because this instructional model allows lecturers, students, and content to be in different locations [4] A salient feature of blended learning is that it accommodates the different learning needs and preferences of the learners. It enhances interactivity, collaboration, and personalization in that materials are self-paced and accessible at any time [5]. Blended learning can take one of the following forms:

1) A combination of web-based technologies to achieve an educational goal;

2) A combination of pedagogical approaches (e.g., constructivism, behaviorism, cognitivism) to produce an optimal learning outcome. In such a case instructional technology may or may not be used;

3) A combination of instructional technology with face-to-face teacher-led training; or

4) A combination of instructional technology with actual job tasks [6].

In a similar vein, Sloman [7] argues that blended learning should not simply be considered in terms of delivery and technology. He is of the view that the concept of blended learning needs to be extended beyond the use of technology. For him, to get the blend right we need to vary learning methodology and to understand what motivates learners, the enrichment programmes and support they need and the implementation of intervention programmes, if needed.
Blended learning is undoubtedly beneficial to both learners and institutions. It facilitates ubiquitous learning. That is, learning has become possible any time, any place [8]. This flexibility of access to learning reinforces the student's autonomy and reflection. It supports active learning and creates opportunities for collaboration at a distance. It is cost and resource effective [5], [9], [10]. It also promotes student satisfaction. Studies indicated that blended learning motivates learners and enables them to become more involved in the learning process. As a result, learners have shown heightened levels of commitment and perseverance [11], [12]. Other studies found that students have shown higher satisfaction with blended learning courses than purely face-to-face courses [9], [13].

\section{MODELS OF BLENDED LEARNING}

Blended learning is a system of instructional design that can adopt/use various types of teaching and learning experiences. According to the Christensen Institute, there are four models that are most commonly implemented in schools today, as we can see in the following figure



Fig. 3. Models for blended learning [14].

In a Rotation Model, learners are involved in a number of different activities or centres, including whole-group or small group instruction, peer-to-peer activities, pencil-and-paper assignments, as well as individual tutoring. The rotation model involves different forms of implementation as follows:

1) Station Rotation in which "students rotate on a fixed schedule or at the teacher's discretion among classroom-based learning modalities". [14]. That is, learners go through a number of activities (e.g. pencil-and-paper assignments) in the classroom during one or more class periods. The rotation includes at least one activity for online learning.

2) Individual Rotation model occurs when each learner is assigned with a specific individualized schedule that includes offline learning in the classroom and online learning or activity with the help of a technology-based assessment tool.

3) Lab Rotation is a form of blended learning in which learners doing a particular course "rotate on a fixed schedule or at the teacher's discretion among locations on the brick-and-mortar campus" [14]. One of these modalities takes place in a lab for online learning. Unlike the Station-Rotation model, learners do not stay in one classroom but rather rotate among locations on campus.

4) A flipped classroom is a form of blended learning in 
which students are introduced to content at home, and practice working through it on campus. For example, students can watch a YouTube video at home, then come to school to do assignments and projects.

The second model of blended learning is known as Flex Model. Here, online learning is the backbone of a course or subject. Learning takes place on-site in a brick-and-mortar setting using an online instructional tool, with the teacher providing support as necessary. Learners in a flex model "move on an individually customized, fluid schedule among learning modalities" [14] and the teacher's support can vary based on each implementation model. While some implementations may require extensive face-to-face support, others may require minimal support.

The third model is called Self-Blend model and it takes place when learners choose to take one or more courses entirely online to supplement their traditional courses and the teacher-of-record is the online teacher. Learners may choose between taking the online courses on campus or outside campus. It differs from full-time online learning in the sense that it is not a whole-class experience. Learners self-blend some individual online courses and take other courses at a brick-and-mortar campus with face-to-face teachers.

The Enriched Virtual Model is the fourth form of blended learning adopted by the Christensen Institute. Here, learners have face-to-face learning periods with their teachers, and the rest of their coursework is finalized remotely, outside the campus. The model requires formal, regularly scheduled instructional sessions even though students may not meet with their instructor on a daily basis.

We concur with Cleveland-Innes \& Wilton that blended learning varies in design and implementation across teachers, programmes and schools [15]. Hannon and Macken identified three models of blended learning that can be more fitting in a university setting. These models are blended presentation and interaction, blended block and fully online, as is clear in the following figure [16].
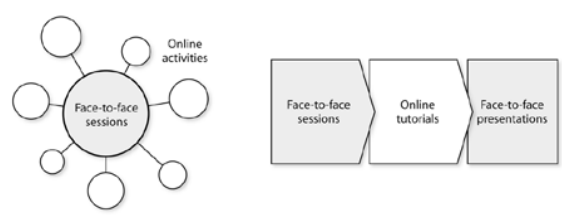

Fig. 4. Models of blended learning [16]

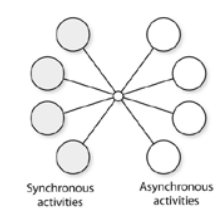

In the first model, presentation and interaction are blended. The primary component in this model is classroom engagement. Out-of-class online exercises, on the other hand, serve as a support. A common example of this model is the flipped classroom. The second model is known as the blended block model. It is also known as the programme flow model. For pedagogical reasons and practical constraints, a sequence of activities, or blocks is structured to incorporate both face-to-face learning and online study. The third model is fully online. However, the blend takes place through incorporation of synchronous learning and asynchronous sessions or activities.

It is worthwhile to note that blended learning is not a haphazard addition of technology to a particular existing course. It is rather a well-woven integration of face-to-face instruction and online learning using the best disruptive technologies. The three models suggested above "provide initial frameworks for the deliberate structuring of blended learning to improve learning outcomes" [15]. In our view, all the models above complement one another and are valid on their own. A qualified teacher is one who can choose the model that can best achieve the pedagogical needs of the course and overcome the practical constraints in terms of time and place.

\section{BLENDED LEARNING IN AFL AND ASP}

Blended learning has been given adequate attention in teaching various foreign languages including Arabic. A considerable number of studies dealt with one or more forms of blended learning. Some of these studies are surveyed below.

Bin Tahir, Mufidah, \& Islamy conducted a study on the influence of a blended learning approach for teaching Arabic as a foreign language at the Islamic State University in Indonesia. The study included 60 participants, 30 students in the experimental group, and 30 in the control group. The findings of the study indicated that the students' scores in writing witnessed remarkable improvement as opposed to their scores in grammar. In general, the post-test scores of the students of the experimental group were higher than the scores of the control group students. The study recommended a further investigation of the use of blended learning for teaching other language skills [17].

AlNajdi designed a blended learning environment for teaching Arabic Alphabet for non-Arabic speakers at an American elementary school based on ASSURE model. The blended content was designed with a view to enabling children in particular to learn the Alphabet of the Arabic language that is likely to create some challenges to them. The blended lesson used in the study was created using google applications and a mobile application called Nan and Lyly. In addition to handwriting in the face-to-face class meeting, children were instructed to use the application for practice. Students were given a tutorial on the use of the lesson's website. The study concluded that the writing, pronunciation, and reading of the learners improved, but writing skills take more time than pronunciation and reading [18].

Alasraj \& Alharbi compared the effect of the use of a blended learning in teaching Arabic as a second language with the use of a traditional approach at the Islamic University in Madinah. 62 students participated in the study. Quizzes were given to the students over a period of five weeks. A questionnaire was also given to them. The findings indicated that the use of blended learning was found to be more effective than traditional learning [19].

Osman \& Hamzah conducted a study at the University of Sultan Zainal Abidin, Malaysia and it involved 248 students to find out to what extent university students were prepared to learn Arabic via a blended learning approach. Participants were requested to respond to a 5-point Likert scale questionnaire. The findings reported that the existing facilities provided by the university can make blended learning a reality. Wireless connection is provided by the university throughout the campus. Learners themselves are in a state of readiness for this form of learning as $96 \%$ of them 
have their own laptops and students are internet-savvy. The study recommended the need for further studies to investigate the design and development of successful blended learning in teaching and learning Arabic language [20].

In a similar vein, Al-Madani investigated the effect of a blended Learning approach compared to a traditional learning approach in teaching Arabic for grade 5 students studying a textbook titled لغتي الجميلة (My Beautiful Language) and to what extent the approach contributes to the development of their verbal creative thinking. The participants of the study were 49 students, 25 are males in the experimental group and 24 females in the control group. The study concluded that there is a statistically significant difference $(\alpha \leq 0.05)$ between the mean scores of the two groups in the achievement post-test and verbal creative thinking post application test. The study also concluded that the experiment group with which the blended approach was used outperformed the control group that was taught using traditional methods in both tests [21]. Similarly, Yassin investigated the use of blended learning for teaching Arabic in an adult class of Arabic as a foreign language in the Singaporean context. The study concluded that blended learning contributes to more effective learning environment. It promotes problem-based learning (e.g. student wiki) and assists learners to be more autonomous and responsible for their learning. It also enhanced their information and communication (ICT) skills. The study pointed out that the main hindrance to effective blended learning lies in the fact that educational institutions and language centers lack a framework or policy to implement blended learning classes [22].

As for the use of innovative technology in teaching Hadith and its sciences, a study was conducted on BA degree students in the Department of Qura'n and Sunnah at a public university in Malaysia with a view to finding out the impact of software apps and websites on studying Hadith. The study concluded that $68 \%$ of the participants believe that the use of software and websites enhanced their knowledge of Hadith and its sciences [23]. A similar study was conducted by Usman, who explored the use of information and communication technology (ICT) in teaching Arabic and Islamic studies in Nigeria. The results of the study demonstrated that information and communication technology (ICT) if properly harnessed and used will play a vital role in enhancing the quality of teaching and learning of Arabic and Islamic Studies. The study, however, emphasized that the use of ICT especially in developing countries like Nigeria faces many challenges [24].

Anwar \& Taher investigated the possibility of innovation in Hadith studies in Islamic schools. The study pointed out that the teaching of Hadith at Islamic schools needs to be revisited. It stressed the significance of using modern technology and teaching methods to keep abreast with the requirements of this era and to encounter contemporary challenges. The study recommended that a model methodology of teaching and a new syllabus of Hadith studies is required. Modern technology can play a vital role in that [25].

Likewise, Hassan diagnosed the situation of using technology in the teaching of Shari'ah sciences. The study indicated that most Arab and Islamic schools and universities fall short to integrate technology in the teaching of Shari'ah courses. Part of the problem is attributed to the fact that the teachers of such courses lack the technological competence that enables them to use digital tools in teaching [26].

It is obvious from the above survey of studies that they deal with the significance of blended learning in teaching foreign language skills and Shari'ah courses and the obstacles that encounter its implementation. Other small-scale studies dealt with the attitudes of the participants towards blended learning. However, such studies involve limited lessons of blended learning and they revolve around the use of one or more tool of disruptive technology. Our study is empirical and a part of a wider action research project that involves the design of a blended programme in the light of NQF, instructional design models and a myriad of Web-based and Mobile Assisted Language Learning (MALL) tools. The project also investigates the attitudes of the learners towards such a programme. As far as we know, there is no study that attempted to design a fully-fledged approach to the teaching of Arabic for Shari'ah purposes in South Africa or elsewhere. Despite the fact that technology is widely used in the promotion of the Islamic call mainly through audio-visual materials (e.g. YouTube, recordings, webpages, etc.), some Shari'ah teachers are technophobic. They are not only averse to use technology but they sometimes claim that it can be very destructive and its use should be kept to the minimum.

\section{MEthodology}

TABLE I: A SUMMARY OF TASKS AND OUTPUTS IN THE PROPOSED SYLLABUS

\begin{tabular}{|c|c|c|}
\hline Learning outcome & NQF Competency & Activity \\
\hline Pre-lesson & Knowledge & $\begin{array}{l}\text { KWLQ (know, } \\
\text { want to know, } \\
\text { learned, questions) } \\
\text { - Entrance ticket- } \\
\text { video watching }\end{array}$ \\
\hline $\begin{array}{l}\text { Read the Hadith in a } \\
\text { correct language. }\end{array}$ & $\begin{array}{l}\text { Knowledge- } \\
\text { Communication } \\
\text { skillS }\end{array}$ & $\begin{array}{l}\text { Reading } \\
\text { Listening- } \\
\text { Watching video }\end{array}$ \\
\hline $\begin{array}{l}\text { Find out the } \\
\text { meaning of the key } \\
\text { words in a Hadith. }\end{array}$ & Knowledge & $\begin{array}{l}\text { Dictionary } \\
\text { work-Matching } \\
\text { exercise- flash cards }\end{array}$ \\
\hline $\begin{array}{l}\text { Derive } a h k \bar{a} m \text { (legal } \\
\text { rulings) from the } \\
\text { Ahādith studied. }\end{array}$ & $\begin{array}{l}\text { Theoretical } \\
\text { Knowledge- } \\
\text { Communication } \\
\text { skills }\end{array}$ & $\begin{array}{l}\text { Comprehension - } \\
\text { discussion- } \\
\text { application- debate }\end{array}$ \\
\hline $\begin{array}{l}\text { Show the } \\
\text { contemporary } \\
\text { relevance of the } \\
\text { Ahādith. }\end{array}$ & $\begin{array}{l}\text { Applied knowledge } \\
\text { Autonomy, } \\
\text { Responsibility\& } \\
\text { Context } \\
\text { competencies }\end{array}$ & $\begin{array}{l}\text { Comprehension- } \\
\text { discussion- } \\
\text { application- debate }\end{array}$ \\
\hline Beyond the text & All the above & $\begin{array}{l}\text { Written or spoken } \\
\text { assignment }\end{array}$ \\
\hline
\end{tabular}

The present paper is based on a solid theoretical framework that stems from common models of blending learning and the latest trends in instructional design. The 
main objectives of the course were considered in the development of materials for each unit. Each unit starts with learning objectives that have been clearly articulated and teamed up with one or more NQF competency or domain. Suitable activities were designed to assist students in the achievement of the learning objectives. A summary of tasks and outputs of each lesson can be shown in the Table I.

To produce an effective instructional product and to achieve the desired goals, we have then adopted the ASSURE instructional design model, which consists of the following steps:
A: Analyze Learners
S: State Objectives
S: Select Methods, Media, and Materials
U: Utilize Media, Materials, and Methods
R: Require Learner Participation
E: Evaluate and Revise.

ASSURE model is presented in the following figure



Fig. 5. ASSURE instructional design model.

\section{THE DESIGNED SYLlabUS}

In this section, the designed blended syllabus will be stated along the lines of the ASSURE model with special reference to one of the lessons in the Hadith module. The lesson is about Al-halāl wa al-harām [The Lawful and the Prohibited] and it is available via this link http://bit.ly/2PIPCh6

\section{A. Analyze Learners}

This is a phase that takes place before the start of any programme. The proposed syllabus is for undergraduate BA learners of Arabic as a foreign language in a multilingual society. The design of an effective syllabus/learning units starts with a careful analysis of learners. This analysis may include the needs of the learners and their attributes. A syllabus designer needs to familiarize himself with the cognitive, physiological, affective and social characteristics as well as their prior knowledge, competencies and learning styles. The majority of students accepted to the BA programme at IPSA can be categorized under a level of cognitive development Perry called dualism [27]. A student at this level of maturity has a belief that knowledge must be true and/or absolute. They tend to absorb theoretical knowledge transmitted in the lecture/lesson/unit and accept that it must be true. Students at this stage are likely to be uncomfortable with assignments that ask for their opinion about certain issues or stances; they expect authority to reveal the truth to them. Students at the stage of dualism are also reluctant to participate in activities that involve collaborative learning with their peers. These students are more accustomed to the instructor-led style of interaction and may not be ready to thrive in a student-centered environment. It is incumbent upon syllabus designer to encourage learners and motivate them to overcome those limitations and to move further onto other stages. Those stages are multiplicity and pluralism. In the former, students approach or analyze an issue/argument/topic from multiple contexts and perspectives. In the latter, learners adopt multiple commitments to define their identity and values. As for the prior competencies of the learners, it should not be taken for granted that all the competencies of the preceding NQF level (i.e., NQF4) were achieved. Therefore, IPSA accepts the students based on strict criteria including entry test in Arabic language and Qura'n recitation and memorization skills. Finally, the syllabus was designed with the assumption that students tend to have various learning styles (e.g. auditory, visual, and tactile) and a good syllabus is one which strikes balance among all those styles.

\section{B. State Objectives}

The second step in the ASSURE Model starts prior to instruction and it is concerned with stating standards and objectives for the learning lesson/module/unit. The main objectives of the module have been clearly articulated by the institution as follows:

- The main objective of the module is to introduce the student to the sciences of Hadith and to build on the student's knowledge of Arabic through the medium of Hadith text reading and memorization.

- To introduce students to expanded features of Prophetic practice and guidance, primarily relating to ethics but including law and belief is to induct the student to what many scholars regard as among the most important texts in Isläm and develop his/her ability to use and reference these texts.

- Furthermore, it is to enable students to derive $a h k \bar{a} m$ [legal rulings] from the Ahādith studied, especially on the basis of comprehending the underlying spirit and meaning of the Ahädith, transcending the immediate literal implications where applicable.

- Students will be mentored to develop a sense of realizing the contemporary relevance of the Ahädith, while appreciating their original context[28].

Our syllabus consists of a number of units and each unit is made up of a number of lessons. Each lesson starts with clear learning objectives that also lead to the achievement of the general objectives of the course. The objectives can also be used in assessing the performance of the students. Consider for example, the learning objectives of a lesson titled Al-halāl wa al-harām [The Lawful and the Prohibited].

\section{Select Strategies, Technology, Media, and Materials}


The third stage in the model deals with the selection of strategies, technology, media, and materials. At this stage, the instructional materials and strategies, technological tools, and media that will serve the learning objectives of the lesson/module in face-to-face or hybrid teaching are carefully chosen. For an effective implementation of the blended programme, we require a fully-fledged multimedia lab for on-site classes and tablets or laptops for off-site sessions. In each lesson, we have used several instructional methods to achieve the lesson's objectives. Some of those techniques are collaborative learning, project-based learnings, khațābah presentations, debating and discussions, brainstorming among others.

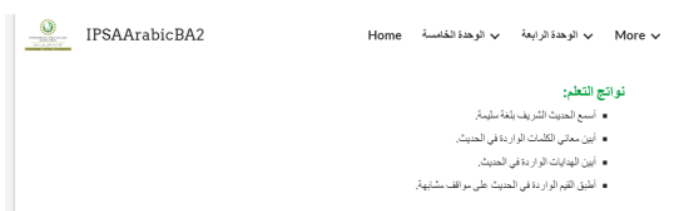

Fig. 5. Snapshot of the learning outcomes of a lesson titled Al-haläl wa al-ḥarām.

\section{Utilize Technology, Media, and Materials}

It is at this stage that instruction begins. The technology and media have been carefully selected, previewed and a dry run of each lesson was conducted before its actual implementation. The learning environment is also prepared. The materials are accessible online, offline and via mobile apps. Learners were prepared and clearly acquainted with the learning objectives of each lesson and the formative and summative assessment they are expected to have. Students are clearly informed about the major assignments they are required to do, the grading system, and the benefits of the programme. Consider for instance the instructional methods used in the teaching of the first unit of the syllabus titled Al-halāl wa al-harām [The Lawful and the Prohibited]. First, a pre-lesson activity that introduces the lesson and examines the learner's prior knowledge was introduced. Learners were asked to name three halāl [lawful] and three harām [prohibited] things they know. After that, the Hadith was introduced and read in the class. Then, a video of the Hadith was presented to help students read, memorize, and pronounce it correctly. The third step aims to familiarize the learners with the meaning of the key terms/concepts in the Hadith. Various vocabulary exercises such as spelling, and flash cards are used. The legal rulings of the Hadith and its moral lessons were then introduced. Students were asked to apply those rulings to current situations and scenarios. A collaborative activity was then introduced. Students were asked to link the Hadìth under investigation with other Ahāìith and Qura'nic verses. Students were asked to answer a number of questions related to the second legal ruling of the Hadith, namely, the soundness of the hearts and the benefits of avoiding doubtful matters. Finally, a YouTube video about الصيد الحرام [forbidden hunting] was introduced and students were asked to answer a number of multiple choice and true/false questions that were inserted in the video. The blend takes place across the board. Despite the fact that all the components of the lesson can be implemented in a traditional setting, they have been supported by technology-enhanced activities that can be done in the classroom or outside it. The following table summarizes the instructional strategies and activities which are used in the lesson.

TABLE II: INSTRUCTIONAL STRATEGIES AND ACTIVITIES IN THE $A L-H A L \bar{A} L$

\begin{tabular}{|c|c|c|c|}
\hline \multicolumn{4}{|c|}{ WA AL-HAR $\bar{A} M$ LESSON } \\
\hline $\begin{array}{c}\text { Instructional } \\
\text { step } \\
\end{array}$ & Activity & Technology & website \\
\hline $\begin{array}{l}\text { Pre-lesson } \\
\text { activity }\end{array}$ & $\begin{array}{l}\text { Question-answer } \\
\text { Brainstorming }\end{array}$ & Google form & https://bit.ly/3h72GaT \\
\hline \multirow[t]{3}{*}{$\begin{array}{l}\text { Read \& } \quad \& \\
\text { memorize } \\
\text { Hadith }\end{array}$} & & $\begin{array}{l}\text { YouTube } \\
\text { video }\end{array}$ & $\begin{array}{l}2=0 \\
\text { http://bit.ly/2ZYqu33 }\end{array}$ \\
\hline & & Recording & https://vocaroo.com/ \\
\hline & & Cloze-exercise & \\
\hline \multirow[t]{2}{*}{$\begin{array}{l}\text { Introduce key } \\
\text { terms }\end{array}$} & $\begin{array}{l}\text { Matching } \\
\text { exercise } \\
\text { Vocabulary quiz }\end{array}$ & $\begin{array}{l}\text { Interactive } \\
\text { embedded } \\
\text { activity }\end{array}$ & http://bit.ly/2sOqT2n \\
\hline & & Quizlet & 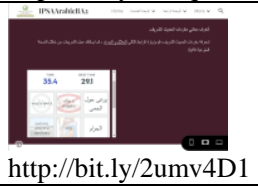 \\
\hline \multirow[t]{2}{*}{$\begin{array}{l}\text { Conclude the } \\
\text { first ruling of } \\
\text { the Hadith }\end{array}$} & $\begin{array}{l}\text { Discuss } \\
\text { Identify }\end{array}$ & $\begin{array}{l}\text { Interactive } \\
\text { embedded } \\
\text { quiz }\end{array}$ & 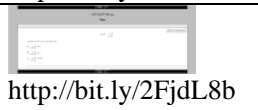 \\
\hline & & $\begin{array}{l}\text { A } \\
\text { short-answer } \\
\text { Quiz }\end{array}$ & http://bit.ly/2un4mdx \\
\hline $\begin{array}{l}\text { Cooperative } \\
\text { learning }\end{array}$ & $\begin{array}{l}\text { Question } \\
\text { Answer }\end{array}$ & $\begin{array}{l}\text { Interactive } \\
\text { embedded } \\
\text { quiz }\end{array}$ & $\overline{\text { http://bit.ly/37Brhjn }}$ \\
\hline $\begin{array}{l}\text { Listening } \\
\text { comprehension }\end{array}$ & YouTube video & $\begin{array}{l}\text { Interactive } \\
\text { video quiz }\end{array}$ & http://bit.ly/2ZSfhYc \\
\hline
\end{tabular}

\section{E. Require Learner Participation}

The designed syllabus is learner-centred to a great extent. A learner-centered syllabus puts the learner at the heart of the learning process. The participation of the learners is required in various stages of the lesson. Interactivity is the crux of the matter here. Students do not have to watch a pre-lesson videos alone, but they need also to comment on it or summarize its content. As shown in the above section, they have to read the Hadith and listen to it. They can do a lot of interactive activities throughout the lesson. Discussion, debating and role-playing activities are given. We concur with Elliott (2000)'s view that learners need to be involved in eight literacies to achieve the desired learning outcomes. Those literacies are text literacy, computer literacy, distance literacy, cyber-learning literacy, visual literacy, audio literacy, and videos literacy [29]. Students' participation should be encouraged at all the domains of NQF, namely knowledge, skills and competencies. 


\section{F. Evaluate and Revise}

This is the final step in the ASSURE model. Teaching strategies, technological tools, media, and materials utilized in the syllabus need to be evaluated. The evaluation process aims to find out whether a lesson/syllabus meets the learning objectives/outcomes and if assessment is in line with those objectives or not. Evaluation can also attempt to find out areas of improvements of lessons/materials, the effectiveness of the selected media and technology, the introduction of new tools and the exclusion of some existing ones as well as the modification of some activities. In the designed blended syllabus, evaluation takes place through formative assessment in each step of the lesson/unit, as shown in Table 2 above. In addition, the evaluation of students takes place through major assignments as well as through gamified activities in each lesson.

Evaluation and assessment take place also through the gamified individual exercises in each unit. For instance, in the lesson under investigation a game show activity in which students take turns answering multiple choice or true and false questions was proposed. This type of activity enables the students to review the lesson content in a motivating manner. A game-based activity to check that the students understand the key concept or terms of Hadith was also given. In such an activity, students are required to match related items. This can enhance one-to-one correspondence and working memory. A Super Sort game-based activity in which students are asked to sort items into two categories (e.g. the permissible and the forbidden), is also given. This kind of activity helps learning through logical thinking, classification and grouping. A common gamified activity is also known as Speedup activity. This is a racing quiz in which students answer true or false questions or multiple choice quickly and correctly. The following table shows how the proposed lesson is gamified in the syllabus

TABLE III: GAME-BASED ACTIVITIES IN THE HADITTH MODULE

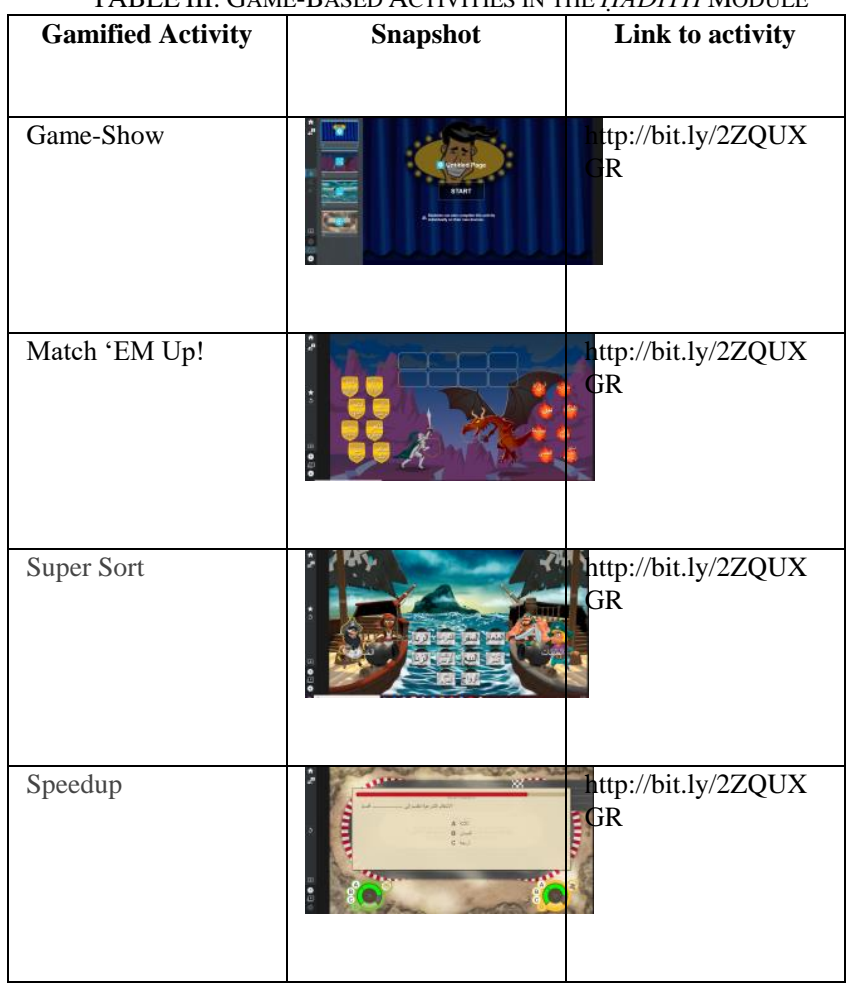

It is worthwhile to mention that students can get immediate feedback in all the designed activities. Feedback from students is also necessary at this stage. Students can be asked to respond to a survey or a questionnaire. Feedback from them can give us an idea about their attitudes towards the programme, the technology and materials used in it. The constructive feedback of the learners is always welcome in technology-enhanced blended programmes. They are open to updates and there is always a room for improvement.

\section{CONCLUSIONS AND IMPLICATIONS FOR FUTURE PRACTICE}

The study reported on the design of blended learning materials for teaching a 5-NQF level Hadith module in a South African tertiary context. The paper has concluded that an effective instructional blended approach needs to be well structured. It should also include carefully chosen motivating learning materials and activities. Taking the NQF competencies as its point of reference, the study has also adopted ASSURE instructional model in the design of the syllabus. The development of the blended materials and website follow the five phases of the ASSURE model. In other words, the study has analyzed the learners who are supposed to do the course and it has stated the objectives of the module and the programme. In addition, it has selected methods, media and materials before the beginning of instruction. The careful implementation of the above phases will definitely lead to media, materials and methods that can motivate the learners and enhance their knowledge as well as skills and competencies. The designed syllabus/website employed various types of activities that can be used in a traditional setting or/and online. Various types of web-based activities were created using different learner-friendly web 2.0 tools. The designed syllabus is learner-centred and the participation of the learners take place through collaborative oral and written activities. The syllabus has also paid adequate attention to revision and evaluation of the lesson, module and the entire programme. Students were given instant feedback in almost all the designed activities. The study has therefore shown how instructional design models such as ASSURE can be effectively used in developing both traditional and e-learning courses and educational programmes. Undoubtedly, the adoption of such models can minimize the degree of haphazardness found in many designed syllabi.

Feedback from the learners was never undermined and their attitude towards the designed blended approach will also be investigated in a subsequent paper. The designed syllabus will be evaluated through students' and teacher's surveys. It is our attention to keep updating the designed syllabus and to implement it at IPSA and similar institutions such as Madina Institute in the short and medium terms and data collected from teachers and students will be used to assess the effectiveness of the syllabus and to make the blend more benefitial and learner-friendly. As we have indicated earlier, the present study is the first component of a wider action reseach project that will incorporate the latest trends in blended learning especially in this trrying time of Covid-19. 


\section{REFERENCES}

[1] SAQA, Level Descriptors for the South African National Qualifications Framework, Pretoria, SAQA, 2012, p. 4.

[2] O. Delialioglu and Z. Yildirim, "Students' perceptions on effective dimensions of interactive learning in a blended learning environment," Journal of Educational Technology \& Society, vol. 10, no. 2, pp. 133-146, 2007.

[3] D. R. Garrison and N. D. Vaughan, Blended Learning in Higher Education: Framework, Principles, and Guidelines, John Wiley \& Sons, 2008.

[4] N. Williams, W. Bland, and G. Christie, "Improving student achievement and satisfaction by adopting a blended learning approach to inorganic chemistry," Chemistry Education Research and Practice, vol. 9, no. 1, pp. 43-50, 2008.

[5] C. R. Graham, "Blended learning systems: definition, current trends, and future directions," in The Handbook of Blended Learning: Global Perspectives, Local Designs, Curtis J. Bonk and Charles R. Graham, Eds. San Francisco, CA: Pfeiffer, 2006, pp. 3-21.

[6] M. Oliver and K. Trigwell, "Can blended learning be redeemed?" E-Learning and Digital Media, vol. 2, no. 1, pp. 17-26, 2005.

[7] M. Sloman, "Making sense of blended learning," Industrial and Commercial Training, vol. 39, no. 6, pp. 315-318, 2007.

[8] B. Cope and M. Kalantzis, "Ubiquitous learning: An agenda for educational transformation," Ubiquitous Learning, pp. 3-14, 2009.

[9] C. A. Twigg, "Improving learning and reducing costs for online learning," Educause Review, pp. 28-38, 2003.

[10] N. Vaughan, "Perspectives on blended learning in higher education," International Journal on e-Learning, vol. 6, no. 1, pp. 81-94, 2007.

[11] M. Wang, R. Shen, D. Novak, and X. Pan, "The impact of mobile learning on students' learning behaviours and performance: Report from a large blended classroom," British Journal of Educational Technology, vol. 40, no. 4, pp. 673-695, 2009.

[12] V. Woltering, A. Herrler, K. Spitzer, and C. Spreckelsen, "Blended learning positively affects students' satisfaction and the role of the tutor in the problem-based learning process: Results of a mixed-method evaluation," Advances in Health Sciences Education, vol. 14, no. 5, p. $725,2009$.

[13] R. Owston, H. Wideman, J. Murphy, and D. Lupshenyuk, "Blended teacher professional development: A synthesis of three program evaluations," The Internet and Higher Education, vol. 11, no. 3-4, pp. 201-210, 2008.

[14] H. Staker and M. B. Horn, Classifying K-12 Blended Learning, Innosight Institute, 2012.

[15] M. Cleveland-Innes and D. Wilton, Guide to Blended Learning, Canada: Commonwealth of Learning, 2018.

[16] J. Hannon and C. Macken, Blended and Online Curriculum Design Toolkit, La Trobe University, 2014.

[17] S. B. Tahir, N. Mufidah, and M. I. Islamy, "Blended learning approach in arabic teaching for non-native speaker students," presented at the $3 \mathrm{rd}$ International Conference on Islamic Education (3rd ICIED), Indonesia, III, 2018.

[18] S. M. AlNajdi, "Design a blended learning environment to teach arabic alphabet for non-Arabic speaker children based on ASSURE model," International Journal of Information and Education Technology, vol. 8, no. 2, pp. 128-32, 2018.

[19] A. Alasraj and H. Alharbi, "The effectiveness of blended learning in teaching Arabic as a second language," International Journal of Research in Humanities and Social Studies, vol. 1, no. 1, pp. 13-17, 2014.

[20] N. Osman and M. I. Hamzah, "Student readiness in learning Arabic language based on blended learning," International Journal of Applied Linguistics and English Literature, vol. 6, no. 5, pp. 83-89, 2017.

[21] F. M. Al-Madani, "The effect of blended learning approach on fifth grade student' academic achievement in My Beautiful Language textbook and the development of their verbal creative thinking in Saudi
Arabia," Journal of International Education Research (JIER), vol. 11, no. 4, pp. 253-260, 2015.

[22] M. Yassin, "Blended learning for teaching Arabic in Singapore LISTEMAA3.COM as an example," in Proc. CLaSIC 2016, pp. 428-42, 2016.

[23] M. H. Chowdhury, M. A. Abdul Rab, W. M. Said, N. M. Ghazali, Y. Mohamed, and A. Toure, "Application of modern technology in the study of hadith and its sciences: A case study," Advanced Science Letters, vol. 23, no. 5, pp. 4773-4776, 2017.

[24] A. Y. Usman, "Using information and communication technology (ICT) to enhance the teaching and learning of Arabic and Islamic studies in Nigeria,"J Teach Educ, vol. 2, no. 3, pp. 353-368, 2013.

[25] M. Anwar and N. Taher, "Possibility of innovation in Hadîth studies in Islamic schools," EktaIslamica, vol. 4, no. 1, pp. 403-29, 2016.

[26] A. Hassan, "Tauḍīf Al-Tiqanīyāt al-Ḥadīthah Fī Khidmat al-'ulūm al-Shar'iyah," al- 'ulüm al-shar 'iyah: Tahadiyāt al-wāqi' $q$ wa 'afāq al-mustaqbal, Saudi Arabia: Faculty of Shari'ah Sciences, pp. 436-58, 2018.

[27] W. G. Perry, "Forms of intellectual and ethical development in the college years: A scheme," Jossey-Bass Higher and Adult Education Series, San Francisco: Jossey-Bass Publishers, 1968.

[28] E. Arnold, "Hadith studies review: An Nqf (national qualifications framework) compliance and outcomes-based approach," International Peace College South Africa, 2018.

[29] S. N. Elliott, Educational Psychology: Effective Teaching, Effective Learning, Boston: McGraw-Hill, 2000.

Copyright $\odot 2021$ by the authors. This is an open access article distributed under the Creative Commons Attribution License which permits unrestricted use, distribution, and reproduction in any medium, provided the original work is properly cited (CC BY 4.0).

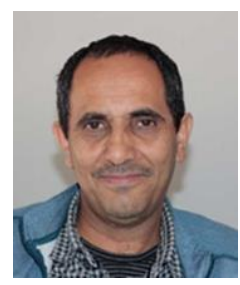

Tawffeek Abdou Saeed Mohammed Al-Kenani is an associate professor of applied linguistics and translation studies. He received his $\mathrm{PhD}$ in linguistics, language and communication studies from the University of the Western Cape, South Africa in 2011. $\mathrm{He}$ is currently the head of the Department of Arabic Studies at the International Peace College South Africa. His research interests include translation studies, computer-assisted language learning, critical discourse analysis and instructional design.

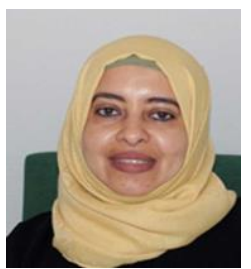

Belqes Al-Sowaidi is an associate professor of applied linguistics and translation studies. She received her $\mathrm{PhD}$ in linguistics, language and communication studies from the University of the Western Cape, South Africa in 2011. She is currently the head of the Department of Translation Studies at the Center of Languages and Translation, Taiz University, Yemen and a research fellow of the University of the Western Cape, South Africa. Her research interests include religious translation and critical discourse analysis.

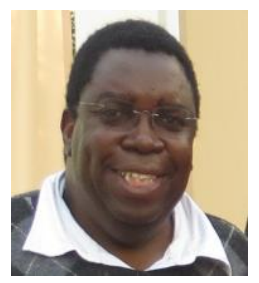

F. Banda is a professor of linguistics and the chairperson of the Department of Linguistics, University of the Western Cape, South Africa. His research interests are wide ranging but located at the intersection of language as social practice, Bantu morpho-phonology and philology, media technologies and remediation, linguistic/semiotic landscapes, multimodality and critical pedagogies, and the simultaneous production/consumption of localization and globalization processes. 